\title{
AN ANALYSIS OF TENTH GRADE STUDENTS' DIFFICULTIES IN COMPREHENDING RECOUNT TEXT
}

\author{
Eko Prayitno, Dewi Sartika, Rekha Asmara \\ Islamic University of Ogan Komering Ilir Kayuagung \\ echodoll.ed@gmail.com,dewisartika@uniski.ac.id,rekha.asmara@gmail.com
}

Submitted: 2020-09-09

Accepted: 2021-05-01

\begin{abstract}
This study aimed to recognize the problems faced by the tenth graders of SMA Negeri 1 Jejawi and to determine the factors that influenced students' difficulties in comprehending recount text. This study was a qualitative research. The subject of the study was the tenth grade students of SMA Negeri 1 Jejawi in academic year of 2019/2020. The techniques of collecting the data were interview and reading comprehension test. To analyses the data, reducing, data displayed, content analysis, and draw conclusion were applied. The result of the study showed that there were $68.7 \%$ students had difficulties in finding the main idea, $70.15 \%$ students had difficulties in understanding vocabulary, $66 \%$ students had difficulties in finding reference, 59.3\% students had difficulties in finding purpose of the text, $67.24 \%$ students had difficulties in finding detail information, and $81.95 \%$ students had difficulties in determining the generic structure of the text. Some factors influenced students' difficulties in comprehending recount text were material that has long passage, limitation of words, learners' background, and environment.
\end{abstract}

Keywords: students' difficulties, reading comprehension, recount text

\section{INTRODUCTION}

Reading is essential to enhance students' knowledge. It is following Hamra and Syatriana (2010: 29) who stated that students who have more knowledge of the reading matter will get more from the material than the less knowledgeable students. Sukarni, et. al, (2017: 215) also explained that reading is about constructing meaning and comprehending written texts. It means that reading refers to the integrated knowledge to comprehend written text and processing activities to construct meaning and to find information from a text so that someone can obtain the knowledge and share it with other people.

In the reading activity, the readers have to catch the point or message of what they read (Anom \& Dahler, 2018: 117). It indicates that comprehension is needed in the reading activity. The way of the readers to build the meaning by having interaction with the text that correlates the readers' previous science and event, the explanation in a text, and readers' attitude toward the text (Pardo, 2004: 272). It meant that comprehension is required when reading the passage to obtain knowledge and to reach the purpose of reading itself. Besides, comprehension is important in the reading process. Without comprehension, the reader hard to know content of the text itself.

Since students' do a process of comprehension in reading activity, the students sometimes get difficulty. As stated by Larasati (2019: 3), the students faced difficulties in 
reading are due to several factors such as uninteresting reading strategy used by the teacher, students' low motivation in reading, and limitation of students' knowledge about vocabulary and grammatical. In short, the students have problems in reading because of the monotonous teachers' strategy, students' motivation, and students' bad in vocabulary and grammar.

In the reading activity, students often find some difficulties in their reading activity, especially in reading recount text. The difficulty is the condition or situation of a thing that is hard to accomplish in comprehending recount text (Aiman \& Fitrawati, 2019: 318). In fact, in recount text, there are three generic structures of recount text, namely orientation that introduces the participants, place, and time in the first paragraph, event(s) that describes a series of events that happened in the past, and reorientation that explains the personal comment of the writer to the story (Deazmi, et. al, 2017: 2). Moreover, Gustina (2016: 10) added that the difficulties may arise in comprehending recount text are decoding, comprehension, and retention in reading recount text, which is indicated the problems such as understanding, analyzing the content of the text, and having limited words and prior knowledge. In short, the problems of students in reading were less comprehension, lacked of analyzing the reading content, and having limited words and prior knowledge.

This study intended to analyze students' problems in comprehending recount text and some factors that influenced it at the tenth graders of SMA Negeri 1 Jejawi.

\section{METHOD}

Before starting this research, some preparation were done such as specifying the research problems into questions, examining studies or the literature about the research topic, deciding the research location, doing preliminary research, and choosing a qualitative methodology. The descriptive qualitative research was applied. According to Creswell (2014), qualitative research is an approach for exploring and understanding the meaning individuals or groups describe to a social or human problemThe tenth-grade students of SMA Negeri 1 Jejawi in the academic year of 2019/2020 were involved. The school was located on Jl. Raya Desa Lingkis Kecamatan Jejawi Kabupaten Ogan Komering Ilir Regency South Sumatera Province. The data were obtained from written test and interview. The test was done to check students' ability to answer the questions. The interview was also applied to obtain detailed information to support the reading test result.

To measure reliability and validity of the instruments, a triangulation technique was used. The kind of triangulation used was method triangulation. The researcher used a reading comprehension test as the quantitative method and interview as the qualitative method. Using 
triangulation, it was expected that the whole and more detailed information from the students about the students' test output and students' difficulties in having the reading test were obtained.

\section{FINDING AND DISCUSSION}

The finding showed that students had problems of reading in terms of finding main idea, grammatical features (vocabulary), reference, purpose of the text, detailed information, and generic structure. The detail explanations were as follows.

First, in determining the main idea, it was found that there were seven questions about finding the main idea in the text. From the table above, it was shown that there were twenty-two correct answers (61\%) and fourteen incorrect answers (39\%) for item number 1, ten correct answers $(27.8 \%)$, and twenty-six incorrect answers (72.2\%) for item number 6, eight correct answers $(22.2 \%)$ and twenty-eight incorrect answers (77.8\%) for item number 11, ten correct answers $(27.8 \%)$ and twenty-six incorrect answers (72.2\%) for item number 13, five correct answers (13.9\%) and thirty-one incorrect answers (86.1\%) for item number 15, fifteen correct answers $(41.7 \%)$ and twenty-one incorrect answers (58.3\%) for item number 18, and nine correct answers (25\%) and twenty-seven incorrect answers (75\%) for item number 22. See Table 1.

Table 1. The Distribution of Students' Score Viewed from Finding Main Idea

\begin{tabular}{|c|c|c|c|c|c|}
\hline No. & $\begin{array}{l}\text { Number } \\
\text { of Items }\end{array}$ & $\begin{array}{l}\text { Correct } \\
\text { Answer }\end{array}$ & $\begin{array}{l}\text { Incorrect } \\
\text { Answer }\end{array}$ & $\begin{array}{c}\text { Percentage } \\
\text { Correct Answer }\end{array}$ & $\begin{array}{c}\text { Percentage } \\
\text { Incorrect Answer }\end{array}$ \\
\hline 1. & 1 & 22 & 14 & $61 \%$ & $39 \%$ \\
\hline 2. & 6 & 10 & 26 & $27.8 \%$ & $72.2 \%$ \\
\hline 3. & 11 & 8 & 28 & $22.2 \%$ & $77.8 \%$ \\
\hline 4. & 13 & 10 & 26 & $27.8 \%$ & $72.2 \%$ \\
\hline 5. & 15 & 5 & 31 & $13.9 \%$ & $86.1 \%$ \\
\hline 6. & 18 & 15 & 21 & $41.7 \%$ & $58.3 \%$ \\
\hline 7. & 22 & 9 & 27 & $25 \%$ & $75 \%$ \\
\hline \multicolumn{4}{|c|}{ Mean of Percentage } & $31.3 \%$ & $68.7 \%$ \\
\hline
\end{tabular}

As a whole, it could be said that there were $31.3 \%$ of 36 students answered the questions correctly and $68.7 \%$ of 36 students answered the question incorrectly.

Second, in the grammatical features (vocabulary), it was found that that there were four questions about understanding vocabulary. The table above showed that there were twenty-one correct answers (58.3\%) and fifteen incorrect answers (41.7\%) for item number 7, seven correct answers $(19.4 \%)$ and twenty-nine incorrect answers (80.6\%) for item number 9, eleven correct answers (30.6\%) and twenty-five incorrect answers (69.4\%) for item number 20, and four correct answers (11.1\%) and thirty-two incorrect answers (88.9\%) for item number 25 . In summary, there were $29.85 \%$ of 36 students answered the questions correctly and $70.15 \%$ of 36 students answered the question incorrectly. See Table 2. 
Table 2.The Distribution of Students' Score Viewed from Grammatical Features (Vocabulary)

\begin{tabular}{|c|c|c|c|c|c|}
\hline No & $\begin{array}{c}\text { Number of } \\
\text { Items }\end{array}$ & $\begin{array}{c}\text { Correct } \\
\text { Answer }\end{array}$ & $\begin{array}{c}\text { Incorrect } \\
\text { Answer }\end{array}$ & $\begin{array}{c}\text { Percentage } \\
\text { Correct Answer }\end{array}$ & $\begin{array}{c}\text { Percentage } \\
\text { Incorrect Answer }\end{array}$ \\
\hline 1. & 7 & 21 & 15 & $58.3 \%$ & $41.7 \%$ \\
\hline 2. & 9 & 7 & 29 & $19.4 \%$ & $80.6 \%$ \\
\hline 3. & 20 & 11 & 25 & $30.6 \%$ & $69.4 \%$ \\
\hline 4. & 25 & 4 & 32 & $11.1 \%$ & $88.9 \%$ \\
\hline \multicolumn{5}{|c|}{ Mean Percentage } \\
\hline
\end{tabular}

Third, in finding a reference, it was shown that there were eight correct answers (22.2\%) and twenty-eight incorrect answers (77.9\%) for item number 4, thirteen correct answers (36.1\%), and twenty-three incorrect answers $(63.8 \%)$ for item number 17 , twenty-one correct answers $(58.3 \%)$ and fifteen incorrect answers (41.7\%) for item number 19, and seven correct answers (19.4\%) and twenty-nine incorrect answers (80.6\%) for item number 24. In conclusion, there were $34 \%$ of 36 students answered the questions correctly and $66 \%$ of 36 students answered the question incorrectly. See Table 3.

Table 3.The Distribution of Students' Score Viewed from Finding Reference

\begin{tabular}{|c|c|c|c|c|c|}
\hline No & $\begin{array}{c}\text { Number } \\
\text { of Items }\end{array}$ & $\begin{array}{c}\text { Correct } \\
\text { Answer }\end{array}$ & $\begin{array}{c}\text { Incorrect } \\
\text { Answer }\end{array}$ & $\begin{array}{c}\text { Percentage } \\
\text { Correct Answer }\end{array}$ & $\begin{array}{c}\text { Percentage } \\
\text { Incorrect Answer }\end{array}$ \\
\hline 1. & 4 & 8 & 28 & $22.2 \%$ & $77.9 \%$ \\
\hline 2. & 17 & 13 & 23 & $36.1 \%$ & $63.8 \%$ \\
\hline 3. & 19 & 21 & 15 & $58.3 \%$ & $41.7 \%$ \\
\hline 4. & 24 & 7 & 29 & $19.4 \%$ & $80.6 \%$ \\
\hline \multicolumn{5}{|c|}{ Mean Percentage } \\
\hline
\end{tabular}

Fourth, in finding the purpose, there were three questions about finding the purpose of the text. The table showed that there were twelve correct answers (33.3\%) and twenty-four incorrect answers $(66.7 \%)$ for item number 2 , fifteen correct answers $(41.7 \%)$ and twenty-one incorrect answers $(58.3 \%)$ for item number 10 , and seventeen correct answers $(47.2 \%)$ and nineteen incorrect answers (52.8\%) for item number 21. To sum up, the students had difficulties in finding the purpose of the text. There were $40.7 \%$ of 36 students answered the questions correctly and $59.3 \%$ of 36 students answered the question incorrectly. It can be seen in Table 4 .

Table 4.The Distribution of Students' Score Viewed from Finding Purpose

\begin{tabular}{|c|c|c|c|c|c|}
\hline No & $\begin{array}{l}\text { Number } \\
\text { of Items }\end{array}$ & $\begin{array}{l}\text { Correct } \\
\text { Answer }\end{array}$ & $\begin{array}{l}\text { Incorrect } \\
\text { Answer }\end{array}$ & $\begin{array}{c}\text { Percentage } \\
\text { Correct Answer }\end{array}$ & $\begin{array}{c}\text { Percentage Incorrect } \\
\text { Answer }\end{array}$ \\
\hline 1. & 2 & 12 & 24 & $33.3 \%$ & $66.7 \%$ \\
\hline 2. & 10 & 15 & 21 & $41.7 \%$ & $58.3 \%$ \\
\hline 3. & 21 & 17 & 19 & $47.2 \%$ & $52.8 \%$ \\
\hline \multicolumn{4}{|c|}{ Mean Percentage } & $40.7 \%$ & $59.3 \%$ \\
\hline
\end{tabular}

Fifth, in detail information, there were five questions in detailed information. The results showed that there were twenty-five correct answers (69.4\%) and eleven incorrect answers (30.6\%) for item number 8, ten correct answers $(27.8 \%)$ and twenty-six incorrect answers (72.2\%) for item number 12, twelve correct answers (33.3\%) and twenty-four incorrect answers $(66.7 \%)$ for item number 14 , four correct answers $(11.1 \%)$ and thirty-two incorrect answers 
(88.9\%) for item number 16, and eight correct answers $(22.2 \%)$ and twenty-eight incorrect answers $(77.8 \%)$ for item number 23. In summary, based on the table above there were $32.7 \%$ of 36 students answered the questions correctly and $67.24 \%$ of 36 students answered the question incorrectly. It can be stated that most students had difficulties comprehending recount text to find detailed information in the text. See Table 5.

Table 5.The Distribution of Students' Score Viewed from Detail Information

\begin{tabular}{|c|c|c|c|c|c|}
\hline No & $\begin{array}{c}\text { Number of } \\
\text { Items }\end{array}$ & $\begin{array}{l}\text { Correct } \\
\text { Answer }\end{array}$ & $\begin{array}{c}\text { Incorrect } \\
\text { Answer }\end{array}$ & $\begin{array}{c}\text { Percentage } \\
\text { Correct Answer }\end{array}$ & $\begin{array}{c}\text { Percentage } \\
\text { Incorrect Answer }\end{array}$ \\
\hline 1. & 8 & 25 & 11 & $69.4 \%$ & $30.6 \%$ \\
\hline 2. & 12 & 10 & 26 & $27.8 \%$ & $72.2 \%$ \\
\hline 3. & 14 & 12 & 24 & $33.3 \%$ & $66.7 \%$ \\
\hline 4. & 16 & 4 & 32 & $11.1 \%$ & $88.9 \%$ \\
\hline 5. & 23 & 8 & 28 & $22.2 \%$ & $77.8 \%$ \\
\hline \multicolumn{4}{|c|}{ Mean Percentage } & $32.76 \%$ & $67.24 \%$ \\
\hline
\end{tabular}

Sixth, in generic structure, there were ten correct answers (27.8\%) and twenty-six incorrect answers $(72.2 \%)$ for item number 3, and three correct answers (8.3\%) and thirty-three incorrect answer (91.7\%) for item number 5. It was shown that generic structure was quite difficult for the students and more than half of the total students got problem in answering the questions. the percentages of difficulty of it can be seen in Table 6 .

Table 6. The Distribution of Students' Score Viewed from Generic Structure

\begin{tabular}{|c|c|c|c|c|c|}
\hline No & $\begin{array}{c}\text { Number of } \\
\text { Items }\end{array}$ & $\begin{array}{c}\text { Correct } \\
\text { Answer }\end{array}$ & $\begin{array}{c}\text { Incorrect } \\
\text { Answer }\end{array}$ & $\begin{array}{c}\text { Percentage } \\
\text { Correct Answer }\end{array}$ & $\begin{array}{c}\text { Percentage } \\
\text { Incorrect Answer }\end{array}$ \\
\hline 1. & 3 & 10 & 26 & $27.8 \%$ & $72.2 \%$ \\
\hline 2. & 5 & 3 & 33 & $8.3 \%$ & $91.7 \%$ \\
\hline \multicolumn{6}{|c|}{ Mean Percentage } \\
\hline
\end{tabular}

Moreover, several factors influenced the students' problems in reading recount text were as follows. First. text material. Students were not interested in reading long passages because they were lazy to read it so that they could not understand the long passage. It indicated that they lacked of motivation to read the long passage. Moreover, students thought that they had to translate all of the words to comprehend the whole reading text that made them feel bored to learn English. Second, lack of vocabulary. Students could not understand the content of the recount text because they did not know the meaning of many words. Third, learners' background knowledge. Students were not interested in learning English because they did not have any desire to read English text and were lazy to read the English text. Besides, they had low interest to learn English that made them dislike English at all. The last, students' learning environment. The class was not clean and neat that made students felt uncomfortable to learn. Besides, students felt sleepy, hungry, and got heated when learning English in the afternoon.

Having analyzing the data, the results showed some results. First, there were $68.7 \%$ of 36 students faced difficulty in finding the main idea in the text. It showed that most of the students had difficulties comprehending recount text to determine the main idea. This matter was caused 
that students were lazy to read the long passage and their ability in comprehending the content of the text was low. It was in line with Satriani (2018:17-20) who stated that the reason of students made mistakes in reading because they did not understand the content of the text that made them were lazy to read. Second, $70.15 \%$ of 36 students faced difficulty in grammatical features in this case understanding vocabulary. They still misunderstood making meaning of synonym and antonym due to have a limitation of words. To comprehend the text, students should master in vocabulary. As supported by Yuliawati (2018: 2), vocabulary play important role in learning language so that students can improve their language skills in reading. Third, there were $66 \%$ of 36 students had difficulties in answering the questions about finding references. Most students did not know how to identify the pronoun and word references well, and understanding the text because of their lack vocabulary and prior knowledge of grammatical features. Moreover, students' ability in finding reference to the text was low. It could be said that students should resolve those problems to comprehend the text well.. Then in finding the purpose of the text, there were $59.3 \%$ of 36 students faced difficulty to answer the questions. The factor that caused students difficult to answer the question was students were lazy to read the long passage. Besides, at the first time when reading the text they did not like the topic because it was uninteresting. As supported by Hasibuan (2018: 132), students could not comprehend the text well because of uninterested in reading the text. Next, there were $67.24 \%$ of 36 students difficult to find stated/unstated detail information. The reason was students' poor ability in identifying the text. They read whole the text to find the answer, and also had low motivation in learning English. It meant that students lacked a strategy to find the answer and had no desire to learn. It was supported by Harida (2014: 187) who stated that students were unable to apply reading strategy and had no motivation and interest in reading. Ganie, et.al (2019: 691) also stated that reading was an attractive subject because students tended to think that this subject was uninteresting that made their motivation was low to learn it. Finally, there were $81.95 \%$ of 36 students difficult to answer the questions about generic structure. More than half of the students faced difficulty in answering the questions. It was because the students did not know what generic structure was and had not comprehend about it. It was in line with Yuliani (2013: .2) who found that some students had problem in deciding generic structure of recount text. Also, Aiman and Fitrawati (2019: 321) described that students did not know the generic structure of the recount text because they lacked knowledge or mastery of vocabulary in comprehending part of generic structure. They generally guessed the answer based on their feeling and lacked concentration in doing it. To be able to answer questions related to the generic structure of recount text, the students needed to increase their knowledge and understanding to comprehend the generic structure of recount text (Deazmi, et. al, 2017: 7). 


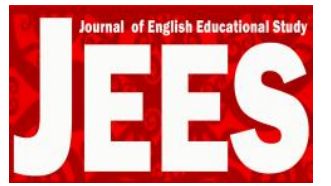

Journal of English Educational Study (JEES)

Volume 4 Issue 1 May 2021 Page 30-38

E-ISSN: 2655-0776

In conclusion, students were difficult to answer the questions of recount text in terms of finding the main idea, understanding vocabulary, reference, determining the purpose of the text searching detailed information, and generic structure.

Besides, several factors influenced the students when they answered the questions such as text materials, students' vocabularies, students' background, and the environment of the classroom. First, reading materials; long passages. When reading the text, students had to comprehend the text itself to take the information. At that time, students needed time to understand the text and the information. However, there was limited time to comprehend the text that made students faced difficulty to comprehend the text and to find the answer from the text. As supported by Shehu (2015: 29), the factor that influences reading comprehension achievement was reading material. It can influence students' achievement if the text given is not at the right level of the difficulty of the students. Second, vocabulary mastery. To understand what the text tells about, students should enrich their vocabulary. It could be the main problem in understanding the text if the students lacked vocabulary. It is related to Ganie, et.al (2019: 691) stated that students were incompetent to know the meaning of the words and were not familiar with the vocabulary in the text. Next, learners' background knowledge. Students had no interest in learning English. They did not like English because it was influenced their ability in comprehending the text. As stated by Shehu (2015: 29), interest is one of the important factors that caused the improvement of students' reading comprehension achievement. Last, the environment. The condition of the class was not clean enough and weather is hot so that students felt uncomfortable to learn English. As Shamaki (2015: 41) stated that one of essential component in the learning environment is the class should be clean, quiet, and comfortable.

To sum up, several factors influenced students' difficulty to comprehend the text when they do reading activity such as the text materials, students vocabulary, learners background, and environment. Students faced difficulty when the teacher give them the test with long passage. Also, students had a limited vocabulary to comprehend the text. besides, the situation of environment and learners' background were also influenced students' comprehension in reading the text well.

\section{CONCLUSION}

The tenth grade students of SMA Negeri 1 Jejawi tend to have problems in six aspects of reading recount text, namely the generic structure of the text, understanding vocabulary, determining the main idea, determining detailed information, finding reference, and finding the purpose of the text. It was happened because of several factors such as materials, vocabulary, learners' background, and environment. In terms of reading materials; students were lazy to 
read the long passage so that made them difficult to find the answer or to get the information from the text. Then the limitation of the students' vocabulary became the factor that influenced students' ability in comprehending the text. Next, learners' background made students were difficult to understand the text. Besides, they did not have an interest in studying English and had obstacles to get the meaning of the text. Last, the condition of the environment in the class that made students got difficulty to get the information from the text.

\section{REFERENCES}

Aiman, U., \& Fitrawati (2019). An analysis on the second year student's difficulties in comprehending recount text. Journal of English Language Teaching, 8(3).

Anom, D., \& Dahler. (2018). The use PQRST strategy to improve students reading comprehension in recount text in the first grade at SMK N 5 Pekanbaru. ELT-lectura: Jurnal Pendidikan 5(2). Retrieved $\quad 2^{\text {nd }} \quad$ December 2019 from https://journal.unilak.ac.id/index.php/ELT-Lectura/article/view/1553

Creswell, J. W. (2014). Research design, qualittative, quantitave, and mixed methods approaches $\left(4^{\text {th }}\right.$ ed). Boston: Pearson Education. Retrieved 24 ${ }^{\text {th }}$ December 2019 from http://basu.nahad.ir/uploads/creswell.pdf

Deazmi, R. C., Tanjung F., \& Roza W. (2017). An analysis of the first year students' ability in comprehending generic stucture of recount text at SMA N 1 Kubung Solok. Retrieved $24^{\text {th }}$ June 2020 from http://www.sciencepublishinggroup.com/j/ajtas

Ganie, R., Deliana \& Rangkuti R. (2019). Reading comprehension problem on English text faced by high school students in Medan. AICLL 2019. Retrieved November $24^{\text {th }}, 2019$, from: https://knepublishing.com

Gustina, R. (2016). Student's difficulties in reading English recount text. Unpublished. Mataram University. Retrieved November $28^{\text {th }}, 2019$ from https://onesearch.id/Record/IOS5428.155

Hamra, A. \& Syatriana E. (2010). Developing a model of teaching reading comprehension for efl students. Makasar. Teflin Journal 21(1).

Harida, E. S. (2014). Students' ability and difficulties in understanding English text. Retrieved June $23^{\text {rd }}, \quad 2020$ from https://www.semanticscholar.org/paper/The-cognitive-andmetacognition-reading-strategies-Hamdan-

Ghaffar/32e922921e8e1fdca21bd36b63cfe45d4de9f64c

Hasibuan, S. F. (2018). The Implementation of trading place strategy to improve of students' ability in reading comprehension of report text at eight grade of MTs S. Al-Husna Marindal Medan academic year 2018/2019. AICLL. Retrieved June 24 ${ }^{\text {th }}, 2020$ from 103.216.87.80/index.php/jelt/article/view/2611 
Larasati, D. (2019). An analysis of difficulties in comprehending English reading text at the eleventh grade students of MA Lab Uin-Su Medan. Unpublished. State Islamic University of North Sumatera. Retrieved March 14 ${ }^{\text {th }}, 2020$ from repository.uinsu.ac.id/7882/

Pardo, L. S. (2004). What every teacher need to know about comprehension. International Reading Association 58(3).

Satriani, E. (2018). Reading comprehension difficulties encountered by English students of Universitas Islam Riau. J-SHMIC, 5(2). Retrieved June $17^{\text {th }} ， 2020$ from https://www.semanticscholar.org

Shamaki. (2015). Influence of learning environment on students' academic achievement in mathematics: a case study of some selected secondary school in Yobe State-Nigeria. Journal of Education and Practice, 6(34).

Shehu, I. (2015). Reading comprehension problem encountered by foreign language students, case study: Albania Croatia. Academic Journal of Interdiciplinary Studies, 4(1).

Shehu, I. (2015). Factors hat influence students reading comprehension achievement in the foreign language. Anglisticum Journal (IJLLIS) 4.

Sukarni, S., Rukmini D., Sofwan A., \& Hartono R. (2017). The effectiveness of strategy-based reading instruction (SBRI) for teaching reading and the students' perception toward the instruction. International Journal of English and Education, 6(3).

Yuliawati, L. (2018). The effect of grammar and vocabulary mastery on students' reading comorehension. Wanastra, .X(1).

Yuliani, E. (2013). Teaching reading comprehension on recount text through heading into questions.Unpublished. Tanjung Pura University.Retrieved June $24^{\text {th }}, 2020$ from repository.unib.ac.id/4421/ 